\title{
Harvard Business School (HBS) Case Method to Teaching English for Business Communication
}

\author{
Wenhua Hsu \\ Department of Applied English, I-Shou University \\ No.1 Sec. 1 Syuecheng Rd., Dashu District, Kaohsiung 84001, Taiwan, R.O.C. \\ E-mail:whh@isu.edu.tw
}

Received: October 23, 2016 Accepted: November 6, 2016 Published: November 7, 2016

doi:10.5296/elr.v2i2.10192ＵRL: http://dx.doi.org/10.5296/elr.v2i2.10192

\begin{abstract}
The present research investigated the effectiveness of Harvard Business School (HBS) case method to teaching English for Business Communication in an EFL context. The HBS case method is a commonly-used approach in the field of business and management to prepare MBA students for the challenges of leadership. In contrast, in the field of English language teaching, task-based learning (TBL) focuses on doing meaningful tasks using the target language. The definitions of tasks and the rationale of TBL are first discussed and then the TBL approach and the HBS case method are compared. The pedagogical framework is underpinned by content-based instruction, business case study and task-based learning, in which each approach has its source and theories to support it. A series of independent-groups t-tests were conducted to compare the English-majoring students' oral performance on business communication with and without the instruction of HBS case method. To find out English majors' perception toward the business case method, questionnaires were distributed as a follow-up study. Results provide some evidence for the effect of the case method on participation. Questionnaires reflect the learners' need for specialist knowledge as well as oral communication skills.
\end{abstract}

Keywords: Task-based learning, Harvard Business School case method, Content-based instruction

\section{Introduction}

English for Specific Purposes (ESP) is a branch of English Language Teaching (ELT) and is considered to be contrasted with English for General Purposes (EGP). Addressing learner specific needs, ESP may take various forms such as English for Business Purposes (EBP), English for Science \& Technology (EST) and English for Medical Purposes (EMP). In terms 
of learning contexts, ESP programs also differ widely. In a normal ESP setting, English learners are currently employed professionals in a certain field. English classes may be arranged for on-the-job language training. In the context of university study, non-English-majoring students need to take English courses in relation to their major subjects. Different from the two situations, applied English or English departments also offer ESP courses to their students in consideration of the demand from the job market.

The current context is where English is not an official language. The participants in this research were university sophomores majoring in English. The English majors take Business English courses mainly for two purposes: preparation for future study in business for a Master's degree and job-oriented preparation. They regard elective EBP courses as a launch pad for their career plan.

\section{Literature Review}

\subsection{English for Business Purposes}

According to Dudley-Evans and St John's (1998) dichotomy, Business English itself is an umbrella term encompassing English for General Business Purposes (EGBP) and English for Specific Business Purposes (ESBP). Broadly, EGBP courses, although set in business contexts, follow EFL course design and can largely be equated with pre-experience extensive courses. ESBP courses are more likely to be post-experience, intensive and company-based. In addition to this dichotomy, there is a further proliferation of terms within business English: English for MBA executives, English for international trade, English for finance and English for secretaries, etc. These terms not only show that EBP practitioners brand their course offerings by developing niches through a proliferation of terms and target different contexts for use of business English, but they also reveal that various EBP programs are designed to meet learner needs.

\subsection{The Pedagogical Framework for English for Business Communication}

Due to lack of specificity of EBP methodology, the methodology in the present EBP context has thus been developed by the teacher-researcher herself. This paper offers a teaching framework for English for Business Communication and outlines the principles of three delivery approaches on which the framework is based. The notions of three approaches are phased into the course: content-based instruction, business case study and task-based learning. The researcher sought to rely on the theories set out in the literature to support the integrated framework and found that each approach itself can stand alone to account for its pedagogical rationale. The three pedagogies are discussed as follows.

\subsection{Content-based Instruction}

Content-based instruction (CBI) programs are characterized by integrated language and content teaching. Spanos (2008) distinguished three fundamental types for CBI:

(1) Content-based language instruction, where topical content is used in the language classroom. 
(2) Language-sensitive content instruction, where language instruction is conducted in the content classroom.

(3) Articulated language and content instruction, where attempts are made to coordinate both content and second or foreign language.

At the tertiary level, Brinton, Snow and Wesche (1989) identified three models for content-based instruction: theme-based, sheltered and adjunct formats according to their relative focus on language and content. Crandall (1993) also classified CBI into three types: (1) content-based language instruction, (2) sheltered subject matter teaching and (3) language across the curriculum. She defined the first type of CBI as a general approach, in which ESL/EFL teachers use academic texts and tasks as a vehicle for developing language, content and study skills. The second type refers to an approach in which subject teachers adapt the language of their texts to make their instruction accessible to students at lower proficiency levels. The third type means an effort to integrate language instruction into all other curricula - an approach where language and content teachers are teamed together and language teachers derive their materials from the content course. The language teacher emphasizes language skills while the content teacher focuses on academic concepts. These three models can be put on a continuum. At one end of the continuum is the content-driven model (the sheltered $\mathrm{CBI}$ ) and at the other end is the language-driven format (the theme-based CBI).

Extended from the content-driven model to the extreme is discipline-based language instruction (Krueger \& Ryan, 1993). The content is normally disciplinary materials. This embraces instruction in non-language courses that makes extensive use of informational resources in a foreign language or in content courses taught in a foreign language. In line with discipline-based model, the sustained notion advocated by Pally et al. (2000) is an important addition to the existing CBI models. She used the term 'sustained content-based instruction' (SCBI) to emphasize that not all content-based curricula feature sustained content. She defined SCBI as studying one content area over time and proposed sustaining a particular content instruction over a semester to lead to deeper engagement with content sources, meaningful content learning and improved language abilities.

In sum, there are several features which distinguished the aforementioned models from each other (Brinton et al., 1989; Pally et al., 2000; Snow \& Brinton, 1997; Wesche, 1993).

1). In the theme-based model, the focus is EFL/ESL learning; in sheltered courses, it is mastery of content materials; in adjunct model, both language and content learning are given prominence. In the sustained model, a single content area is emphasized in depth. In discipline-based courses, academic disciplines are the content organizing principle.

2). In theme-based and sustained courses, language teachers also teach content material; in sheltered and discipline-based courses, subject teachers are responsible for presenting material in the target language in a way that will support language learning; in adjunct courses, each teacher is responsible for his/her subject domain as well as coordination with the other. 
3). In theme-based courses, more attention is paid to language learning, while in sheltered and discipline-based courses, more focus is on specialist content learning. The adjunct program highlights both content and language learning.

The literature review concerning CBI types serves two purposes:

1). To characterize CBI as a methodology with many facets, this review tries to depict the current contexts in which one of the CBI models is used (i.e. theme-based model).

2). A reference to previous CBI models would clarify which aspect of CBI the present pedagogical framework fits conceptually (i.e. more focus on language).

The reason for adopting content-based instruction in an EBP class is that English-majoring students see the need for conveying their business knowledge during business communication in the target language. Incorporating CBI is a natural result of considering such a need.

\subsection{Harvard Business School (HBS) Case Method}

The Harvard Business School (HBS) case method is an integral part of MBA or business and management programs. In this method, students analyze cases of authentic business situations and gain hands-on experience by discussing complex business issues in a relatively risk-free classroom.

Over a century ago, the Harvard Business School first used case studies to teach its graduate students how to analyze actual or simulated business problems. Each year Harvard University spends a huge sum of money and puts splendid human resources on the Committee of Case Development, whose task is to systematically collect data from the companies all over the world as their case resources and write various cases, dealing with different business situations, as business and management training materials (Hsieh, 2010). The content area of case studies covers production, personnel, marketing, finance, legal forms of organizations and international business. The stimulus in each case is a matter of strategic management concern. The HBS case method entails students' active participation in case discussion and may take the form of a role-play, a simulation, a seminar or a panel discussion. It is through such interactions that business management students practice oral expression, a skill crucial for successful business performance. The HBS students are not only required to read a lengthy case, full of business terms and jargons beforehand, but they are also required to engage in a serious debate of the case with other students and write a case analysis afterwards. Following the HBS's training model, business schools around the world have made the HBS case method an integral part of their curricula.

During a business case analysis, students must identify key issues and problems, outline and assess alternative courses of action, and draw appropriate conclusions. The HBS case method can be broken down into the following steps (Power et al., 2014):

1) Realizing the facts surrounding the case.

2) Identifying the problems or key issues.

3) Generating alternative courses of action. 


\section{Macrothink}

4) Assessing or predicting outcomes/ evaluating each course of action.

5) Choosing the optimal solutions.

6) Communicating the results.

Through case analysis, the purpose is to train students to use the following higher-order thinking skills (Emory, 2016):

1). Analyzing, interpreting and assessing data and situations.

2). Diagnosing problems and assessing situations.

3). Forecasting future performance and resources in need.

4). Planning and goal setting.

5). Communicating.

6). Implementing and monitoring plans.

As teaching materials, business case studies can be split into two genres: the written genre and the spoken genre. The cases deliberately contain data overload such as exhibits, figures and red herrings. Decision cases are most often narratives and reality-based descriptions, centering upon a dilemma of a company and telling the story up to a point where the situation calls for action, leaving students to analyze the dilemma, to generate alternatives, and to recommend a decision. The red herrings are (1) detailed narratives, which draw upon richly contextualized and multi-layered accounts of a variety of relevant and irrelevant issues for case analysis, (2) deliberate disparities between the text and the exhibits, and (3) deliberate discrepancies between the quotations from the people in the case and narrative descriptions of what those people actually do or did (Charles, 1988). There are neither 'right answers' nor simple solutions. The ambiguity is intended to serve as the basis for case discussion (Easton, 1992). Moreover, typical business cases end in a cliffhanger to promote reflection and problem-solving as well as open debate.

At Harvard Business School, a case is discussed without interruption for one hour and twenty minutes (Piotrowski, 1996). According to Northcott's (2007) ethnography of an MBA classroom, several patterns of spoken interaction in case discussion can be detected.

1). MBA students tend to use models, checklists, metaphors, mnemonic acronyms frequently. For example, checklists are used to remind them constantly of what the subject matter is. Typical modeling frameworks are pyramids, trees, matrices and flow charts, such as the Boston Consulting Group (BCG) matrix for product portfolio and breakeven diagram for an investment decision. The acronyms themselves form content terms, for instance, SWOT analysis standing for 'strengths, weaknesses, opportunities and threats', and PIMS for 'profit impact of market strategy'. Colloquial metaphors reflect and describe some business situations like 'bull' for the stock market on the rise and 'bear' for the opposite, 'golden parachute' for an executive's intention to save himself from a hostile takeover, and 'poison pills' aiming at reducing the worth of a company once it has been taken over. 
2). MBA students are inclined to engage in reflective conversations in which they name and frame problems, explore chains of references, and then develop courses of action (Schön, 2002). In other words, they think like business managers by practicing reflection-in-action while simulating the role of a professional. A simulation places the learner in a problem-solving situation (Jordan, 1997).

3). In a case discussion, there is an empathic element which can be seen from this question, "what would you do if you were in X's shoes?" Around the empathy, there is a "military flavor" (Charles, 1988, p. 30), implying a series of defense of assertions, confrontation and challenge of opinions during the case discussion.

The complexity of Harvard case task may present a challenge to EBP teachers. However, it is not insurmountable. The researcher wishes to suggest that business case study be divided into several sub-tasks based on the analytical procedures specific to the HBS case method-realizing the facts, identifying the problems, generating alternatives, evaluating alternatives, choosing the optimal solutions and communicating the results. The following overview of tasks and the rationale behind Task-Based Language Learning will aid in understanding how the TBL is compatible with HBS case method and the viability of their incorporation.

\subsection{Task-Based Learning (TBL)}

The notion of Task-Base Learning (TBL) was proposed in the 1980s and became a concern in ESP. The TBL approach is significant for ESP since one of ESP learners' needs is to be able to perform task(s) in relation to their jobs or academic subjects in the target language. Skehan (1998) suggested four criteria to contrast 'task' with 'exercise': (1) meaning is primary; (2) there is a goal which needs to be worked towards; (3) the activity is outcome-evaluated; (4) there is a real-world relationship.

Nunan (1991) classified tasks into two types: real-world tasks and pedagogical tasks. Real-world tasks attempt to simulate in the classroom the types of behaviors that will be required of the learners outside the classroom. The rationale of the pedagogical tasks on the other hand, is that by performing tasks, internal processes of acquisition are stimulated. Pedagogical tasks are thought to provide learners with skills for later real-world tasks. Experience with the task is assumed to help learners transfer to similar situations they might encounter outside the class.

'Task' has been defined in a variety of ways (e.g. Long \& Crookes, 1992; Prabhu, 1987; Richards, J. Platt, \& H. Platt, 1992). Among different task definitions, two features can be summarized: goal-oriented and activity-oriented (Pica, Kanagy, \& Falodun, 1993). By task, Willis (1996) means a "goal-oriented activity in which learners use language to achieve a real outcome" (p. 53). Communication tasks are central to Willis' TBL framework. The use of communication tasks is based on the assumption from the interaction theory within the field of second language acquisition that language is best learned through meaning-oriented interaction. In other words, it is communication tasks that provide such opportunities for interaction. 


\section{Macrothink}

Communication tasks have the following characteristics (Ellis \& Nobuyoshi, 1993):

1) There must be a communicative purpose.

2) There must be a focus on message rather than on the linguistic code.

3) There must be some kind of gap in information.

4) There must be some opportunity for negotiation when performing the task. (p. 204)

Taking tasks as the main element of a syllabus, TBL proponents assume that participation in communication tasks, which requires learners to mobilize and orchestrate knowledge and abilities, will itself be a catalyst for language learning" (Breen, 1987a, 1987b). The emphasis is upon using language to communicate in order to learn.

The learning rationale concerning a TBL approach can be summarized as follows (Ellis, 2000; Skehan, 1998, 2002; Willis, 1996).

1) Promoting negotiation of meaning and thus comprehensible input in the task-based interaction (Krashen, 1985; Long \& Crookes, 1992).

2) Considering learners' needs and incorporating them in the task.

3) Drawing on learners' own input (experience, subject knowledge and intellectual ability).

4) Doing things with language/ using language to exchange meanings for a real purpose.

5) Relating tasks to the real-world relationship/ using authentic tasks/ materials.

6) Focusing on meaning/ emphasizing holistic language use rather than isolated chunks of language use.

7) Integrating the four skills as well as other skills in the task interaction.

8) Being goal-oriented while undertaking tasks.

9) Evaluating outcomes when tasks are completed.

Business case study appears to fulfill some defining characteristics regarding tasks.

1) By drawing upon authentic materials, business case study brings the realities of the business world into the classroom, and hence is related to the real world.

2) The case texts deliberately involve red herrings (e.g. putting in irrelevant issues and a mass of data), information gaps and content discrepancies to encourage students to engage in negotiation and some process of thought.

3) Business case study narrates the problems or decisions that face a company management, telling the story up to a point where students are left to analyze the dilemma and to solve the problems. During the case discussion, students' attention is focused on meaning and they have a goal which needs to be achieved, i.e. recommending the optimal solutions. 


\section{Macrothink

4) A business case has neither right answers nor simple solutions. The ambiguity provides a conceptual problem space for discussion or even open debate.

5) The open-ended nature of case discussion may bring about an unpredictable and emergent process of language use.

The HBS case method can thus be characterized by the following:

1) Drawing on learners' experience and subject matter knowledge (e.g. in the stage/task of identifying the problems in a business case and realizing the facts).

2) Requiring meaning-oriented interaction (e.g. in the stage/task of generating alternatives).

3) Being outcome-evaluated (e.g. in the stage/task of predicting outcomes and evaluating alternatives).

4) Being goal-oriented (e.g. in the stage/task of choosing the optimal solutions).

5) Communicating the results (e.g. in the stage/task of presentation and written report).

6) Using authentic materials reflecting business situations.

From the features above, it is clear that the business case study is a task rather than an exercise. It provides learners with contexts for meaningful practice, emphasizing holistic language use instead of isolated chunks of linguistic components. In terms of learning rationale, the similarities between HBS case method and TBL lead to a viable incorporation.

\section{The Classroom Application of Business Case Study}

Before the classroom discussion of a business case, the teacher-researcher spent two hours teaching the theories of the subject matter involved in a business case and one hour explaining vocabulary use and aspects of grammar as well as reviewing the basic facts of the case with the students. Students were given time to make a list of the main facts they could learn from the case text. This served as a stimulus to thinking and helped to draw out main issues from the case for further discussion. The issues usually had two main parts:

1). Quantitative aspects: financial, marketing, sales and production data.

2). Qualitative aspects: conflict, internal and external threats and opportunities for the company.

Following the pre-case discussion phase, the students worked together in fours on problem-solving tasks. The discussion questions were used to aid the students in uncovering the connections between various case parts. They tried to identify the problems. The intent was to encourage the students' initiative involvement and oral communication in English. Small group discussion at this stage functioned as a cushion against embarrassment and stress before the formal exchange of ideas among all students and the teacher.

While the case was being formally discussed in the whole class, the students put forward alternatives for the solutions of the case problems, arguing for and against the alternatives. Each group of students presented ideas and defend their positions in English. They made 
great efforts to arrive at optimum solutions to the dilemma. Meanwhile the teacher-researcher did not correct their linguistic errors during the discussion so that interruptions could be avoided. After the debate for and against the alternative solutions, the students had to make a final decision about what should be done to solve the case problems. The decision of the optimal solutions may vary from group to group.

The follow-up exercises such as oral presentation, written case reports and interpreting charts or exhibits help to cement the learning.

By this stage, the entire pedagogical framework comprised content-based instruction, the application of HBS case method and business case discussion as well as task-based learning on problem-solving tasks. Therefore, the teacher-researcher was motivated by the concern about (1) the effects of the HBS case method and content-based instruction on oral performance and (2) English-majoring students' perception toward business case study. This research seeks to answer the following questions.

RQ1: Will content-based instruction enhance verbal participation?

RQ2: Will the HBS case method enhance verbal participation?

RQ3: What are students' perceptions toward the teaching methodology for English for Business Communication?

\section{Research Methodology}

The participants came from two EBP classes of forty-nine and fifty English majors at the intermediate level of proficiency. Three business cases from the textbook International Business: Challenges in a Changing World (Morrison, 2015) were used. The classroom data collection spanned two academic years due to only one EBP class available each year. Nevertheless, it is worth noting that the English majors participating in the research were quite homogeneous in terms of their English learning background and little business specialist knowledge. Each class was arranged into groups of four to five people based on the students' choice. The small group discussion for each case was recorded and then transcribed.

To examine whether the students benefit from the instruction of HBS case method and content-based instruction, independent-groups t-tests on the two classes with and without treatments across two business cases were conducted on SPSS 17.0. The measures for oral participation were operationalized as the amount of speech (measured by the number of words uttered), language performance (measured by the percentage of error-free clauses) and content presentation in speech turns (measured by the number of wrong and naïve content turns). Although each speech turn was deemed as a language practice opportunity, the content of the utterance may not be correct. The speech turn involved incorrect fact description, wrong inference, incomplete comprehension and naïve judgment. Students' limited content knowledge might incline them to process the information superficially and thus toward poor solutions to the case problems. Consequently the content error was taken into account as a measure of content display in the speech turn. Each speaker's turn was assessed based on the following criteria. One point was awarded for each turn of wrong and naïve content and the 


\section{Macrothink}

total points were tallied. The total wrong content turns divided by the total persons of a class were the mean content errors per class.

The students with knowledge of HBS case method or content area knowledge were expected to generate more and better talk (in making fewer content and language errors). The treatments involved two classes with and without knowledge of HBS case method and content-based instruction across two business cases respectively. The comparison was therefore straightforward: both Class A and Class B without any approach delivered in case 1 as a baseline; Class A without content-based instruction versus Class B with content-based instruction in case 2, and Class A with knowledge of HBS case method versus Class B without knowledge of HBS case method in case 3. In consideration of lexical levels and the length of a case text, the three business cases selected were at the same level of difficulty.

For coding reliability, one of the researcher's colleagues, who used to teach the same subject, was requested for help. Cronbach's Alpha was calculated using SPSS to test the inter-rater reliability. The $\alpha$ value $(=0.92>0.90)$ reached a substantial level of agreement between the two raters.

To answer the third research question, anonymous questionnaires of six open-ended questions concerning the students' perceptions toward business case study and the teaching framework were distributed at the end of the semester. The responses were classified into several categories based on the gist of their statements together with the count.

The open-ended questions on the questionnaire were:

1). Did you have difficulties in participating in the case discussion? Did the difficulties cause you to talk less?

2). What influenced you to talk or not to talk during the discussion?

3). What did you feel about the business content knowledge instruction before case discussion?

4). In business case study, what knowledge or skills do you think you need most?

5). Do you agree that this course has helped you to enhance your oral communication ability?

6). Would you like your teacher to continue teaching this way?

\section{Results and Discussion}

The first business case served as a baseline as there was no teaching approach given before the case discussion. Table 1 demonstrates that none of the oral participation measures approached significant differences. The results confirmed the homogeneity of the two EBP classes under study. 
Table 1. Statistical results for both classes in case 1 without any pedagogy delivered

\begin{tabular}{|c|c|c|c|}
\hline Measures & Mean & $\mathrm{t}$ & p-value \\
\hline The amount of speech & Class $A=415, S D=135$ & 0.545 & 0.435 \\
\hline Measured by the number of words uttered & Class $B=401, \mathrm{SD}=167$ & & \\
\hline Language accuracy & Class $\mathrm{A}=40 \%, \mathrm{SD}=0.17$ & 0.352 & 0.704 \\
\hline Measured by the percentage of error-free clauses & Class $\mathrm{B}=37 \%, \mathrm{SD}=0.15$ & & \\
\hline Content errors in speech turns & Class $\mathrm{A}=8.46, \mathrm{SD}=2.23$ & 0.548 & 0.585 \\
\hline By the number of wrong and naïve content turns & Class $\mathrm{B}=7.51, \mathrm{SD}=1.98$ & & \\
\hline
\end{tabular}

Note: Class A, $\mathrm{N}=49$; Class $\mathrm{B}, \mathrm{N}=50$. The significance level was set at $\mathrm{p}<0.05$.

\subsection{The Effects of Content-based Instruction on the Quantity and Quality of Speech}

As shown in Table 2, content-based instruction before the case discussion made Class B generate significantly fewer instances of naïve/ unconsidered talk and misconception than Class A but did not enable Class B to outperform Class A in language performance (measured by the percentage of error-free clauses). Even though Class A did not have content instruction about the case topic in advance, Class A still produced better talk than Class B in terms of language accuracy. In other words, CBI did not raise Class B's quality of language use. Ideally, better talk in group discussion involves a good model of language use with peers and content contribution in depth. The results show that the language gap in Class B (poorer language use than Class $A$ in both Case 1 and Case 2) was not filled by content-based instruction, despite better content knowledge display in Case 2.

Table 2. Statistical results for Class A without content area knowledge and Class B with the knowledge in case 2

\begin{tabular}{|c|c|c|c|}
\hline Measures & Mean & $\mathrm{t}$ & p-value \\
\hline The amount of speech & Class $A=510, S D=164$ & 1.63 & 0.055 \\
\hline Measured by the number of words uttered & Class $\mathrm{B}=611, \mathrm{SD}=188$ & & \\
\hline Language accuracy & Class $\mathrm{A}=43 \%, \mathrm{SD}=0.14$ & 0.292 & 0.633 \\
\hline Measured by the percentage of error-free clauses & Class $\mathrm{B}=39 \%, \mathrm{SD}=0.16$ & & \\
\hline Content errors in speech turns & Class $\mathrm{A}=7.29, \mathrm{SD}=2.42$ & 4.514 & $0.009 *$ \\
\hline By the number of wrong and naïve content turns & Class $\mathrm{B}=3.03, \mathrm{SD}=2.33$ & & \\
\hline
\end{tabular}

Note: Class A, N=49; Class $\mathrm{B}, \mathrm{N}=50$. The significance level was set at $\mathrm{p}<0.05$. *=significance. Class B received content-based instruction before the case discussion while Class A did not. 


\section{Macrothink}

Education and Linguistics Research

ISSN 2377-1356

2016, Vol. 2, No. 2

\subsection{The Effects of HBS Case Method on the Quantity and Quality of Speech}

Table 3 reveals that the verbal participation of Class A with the training of HBS case method was significantly greater than that of Class B without the training $(p=.035<.05)$. By self-comparison, Class A also increased their talk from case 1 to case 2 after the training (mean=415 words in case 1 versus mean $=577$ words in case 2 ). However, knowledge of HBS case method did not apparently favor language performance of Class A (the percentage of error free clauses $=38 \%$ for Class A versus $37 \%$ for Class $B, p=0.709>0.05$ ). As to the quality of content presentation (measured by content errors in speech turns), the HBS case method did not cause a significant difference between the two classes. The only salient effect was the amount of talk. The expectation of the impact of the HBS case method on more talk (measured by the number of words) was sustained.

Table 3. Statistical results for Class A with knowledge of HBS case method and Class B without the knowledge in case 3

\begin{tabular}{|c|c|c|c|}
\hline Measures & Mean & $\mathrm{t}$ & p-value \\
\hline The amount of speech & Class $A=577, \mathrm{SD}=112$ & 2.25 & $0.035^{*}$ \\
\hline Measured by the number of words uttered & Class $\mathrm{B}=425, \mathrm{SD}=137$ & & \\
\hline Language accuracy & Class $\mathrm{A}=38 \%, \mathrm{SD}=0.14$ & 0.392 & 0.709 \\
\hline Measured by the percentage of error-free clauses & Class $\mathrm{B}=37 \%, \mathrm{SD}=0.16$ & & \\
\hline Content errors in speech turns & Class $\mathrm{A}=8.49, \mathrm{SD}=2.42$ & 0.514 & 0.497 \\
\hline By the number of wrong and naïve content turns & Class $\mathrm{B}=9.03, \mathrm{SD}=2.33$ & & \\
\hline
\end{tabular}

Note: Class A, N=49; Class $\mathrm{B}, \mathrm{N}=50$. The significance level was set at $\mathrm{p}<0.05$. $*=$ significance. Class A received training of HBS case method before the case discussion while Class B did not.

\subsection{Questionnaire Analysis}

Questionnaire Q1: Did you have difficulties in participating in case discussion? And did the difficulties cause you to talk less? 


\section{Macrothink}

Table 4. Summary of responses to questionnaire Q1

\begin{tabular}{|c|c|c|c|}
\hline Difficult situations & Count & Difficult situations & Count \\
\hline Limited linguistic sources & 3 & No perceived difficulty & 8 \\
\hline Too much terminology & 1 & Short attention span & 1 \\
\hline Not well prepared & 2 & Lack of exam motivation & 2 \\
\hline Lack of content knowledge & 2 & Lack of interest & 1 \\
\hline Inadequate comprehension & 8 & Fear of making mistakes & 1 \\
\hline $\begin{array}{l}\text { A gap between expression and } \\
\text { comprehension }\end{array}$ & 1 & $\begin{array}{l}\text { Difficulty in uttering different } \\
\text { viewpoints }\end{array}$ & 1 \\
\hline No difficulty due to equal status & 2 & & \\
\hline
\end{tabular}

Table 4 gives a snapshot of the difficulty of verbal participation. It could be summed up with four levels: linguistic, cognitive, content parameters and no difficulty. Some students mentioned that limited vocabulary inclined them to produce 'pidgin English', but frequent poor structure and inadequate use of vocabulary still did not impede comprehension. Some indicated that competing for the floor/ taking turns was not perceived as difficult at all. They said that due to the low standard they set themselves, they did not feel discouraged at their low level of English proficiency when their thoughts in mother tongue mode were expressed in simple English. One factor that needs noticing in particular is inadequate comprehension (8 mentions). Some commented that, not understanding the case thoroughly, they simply made utterances without the intention of clarifying ambiguities. The discussion often broke down owing to lack of further development or extension of previous talk.

"I admit that I did not yet master the case, which made me less confident to talk."

"I felt uncomfortable to talk as I didn't understand the case properly. I missed the turns on purpose."

The frequency of mentions in linguistic and cognitive parameters is spread quite equally: (limited linguistic resources, 3 mentions; too much terminology, 1; gap between expression and comprehension, 1) versus (short attention span, 1 mention; lack of exam motivation, 2; lack of interest, 1; fear of making mistakes, 1; difficulty in uttering different viewpoints, 1). However, the content parameters dictating participation (not well prepared, 2 mentions; lack of content expertise, 2; inadequate comprehension, 8) were slightly greater than 'no difficulty'.

Questionnaire Q2: What influenced you to talk or not to talk during the discussion? 


\section{Macrothink}

Table 5. Summary of responses to questionnaire Q2

\begin{tabular}{lrll}
\hline “To talk" factors & Count & Understanding the case well & 6 \\
\hline $\begin{array}{l}\text { Viewing discussion as transmission of } 3 \\
\text { opinions and knowledge }\end{array}$ & Practicing English & 1 \\
$\begin{array}{l}\text { Partners' incomplete utterance } \\
\text { No cause }\end{array}$ & 1 & "Not to talk" factors & \\
Viewing peer discussion as puzzling & 3 & Others' inertia & 2 \\
out meanings & & & 2 \\
Negotiating for real understanding & 4 & Not understanding well & \\
Appealing for assistance & 5 & Little interest & 2 \\
Partners' active participation & 2 & No response & 2 \\
Divergent opinions & 2 & Difficulty in expression & 2 \\
Discussion task itself & 1 & Bad mood & 2 \\
\hline
\end{tabular}

Content knowledge as a trigger to talk was mentioned by 6 students. They pointed out that when they were certain of some case parts, they could talk more. "Not understanding well" was referred to twice as a "not to talk" factor. In general terms, learners are motivated to talk by different factors. Some simply enjoy talking without needing a reason to do so. Some need a firm push from behind as the comment shows, "I was locked in a small group of four and forced to talk", and others benefit from instrumental ends, for instance, for real understanding, assistance and transmission of opinions and so on. The various factors from the responses to Question 2 lead us to believe that peers have an important role in language use in the classroom. Overall the main reason for the influence on "not to talk" seems related to group dynamics. Two out of 13 mentions attributed "not to talk" factor to others" inertia and one to bad mood. Two took the blame for their own inertia and two stated that when no one responded, they would stop talking. Six out of 13 mentions have a direct bearing on content. They pointed out the factors of "not understanding well" (2 mentions), "little interest" (2) and "difficulty in expression" (2) and hence they became more hesitant to talk.

Questionnaire Q3: What did you feel about business knowledge instruction before case discussion? 


\section{Macrothink}

Table 6. Summary of responses to questionnaire Q3

\begin{tabular}{|c|c|c|c|}
\hline Comments & Count & Comments & Count \\
\hline Helpful and useful & 48 & Not adequate & 5 \\
\hline Prerequisite & 20 & Difficult & 8 \\
\hline Interesting \& challenging & 18 & & \\
\hline
\end{tabular}

Forty-eight students out of 99 expressed the view that business knowledge was helpful and useful. Twenty students claimed further that content area knowledge was a prerequisite before the case discussion. Eighteen students revealed their greater interest in business content. Though not taking up a high percentage of the total students' views, thirteen students' comments revolved around two issues: difficulty in comprehending business concepts and business terms ( 8 mentions) and insufficient content instruction ( 5 mentions).

\subsubsection{Student Views on Business Content Instruction}

The responses to Questionnaire Q4 to Q6 reflect the students' perceptions toward the teaching methodology for the course (for the questionnaire Q4 to Q6, see Research Methodology). Some students' comments were not merely "like and dislike" statements. What they said could be perceived to be a reflection of their evaluation of different teaching approaches, and embraced a variety of issues. The bulk of students' preferences (63 out of 99 students) tended to center around business content instruction. They gave reasons for their preferences:

"Business knowledge instruction has made me feel that I am a double major: English major and business minor."

"Business concepts are easily kept in mind once understood."

"I speak more knowledgeably on business than other peers who take language-related subjects only."

"Learning a new content area which I have never touched before makes me feel a sense of achievement."

"We acquired some basic concepts, which are helpful and useful in academic progress and job- oriented settings."

"It has guided us to approach entry-level relevant academic disciplines."

"Without content area knowledge, I don't know how to tackle the case problems and discuss them deeply."

"Specialist knowledge instruction was very interesting and challenging to those who had never learned other academic disciplines beyond English language subjects like us"

The value of CBI was highlighted by students' conception that they were more 
knowledgeable being a double major than being a language single major. Their needs for knowledge of another content area became prominent when chances were given. It is possible that some learners in the general English courses might not have been really interested in the language but studied it simply because it was compulsory. To them, one function of the elective EBP class was to learn specialist knowledge and language at the same time. Such specialist knowledge needs might have dictated their preference for content-based instruction. This can be partly ascribed to the fact that the members of the target group researched were language majors in an EFL context. The EBP class provided them with the opportunity of learning something new and different from the language courses.

Below is what some students said about the impact of content knowledge on their participation.

"More content knowledge would enhance our collaboration. We had a happy experience in case discussion. We helped each other until each of us understood.

"With more content area knowledge, I would be able to talk in depth and breadth."

"Knowledge is power. Content knowledge enables me to talk with confidence."

The comment below represents how some students pointed to the importance of content-based instruction, in particular delivered over a long period of time.

"Content instruction has made us familiar with a certain topic at a basic level but we did not have opportunities to stick with the topic and develop its relevant critical thinking skills both in depth and breadth. We hope to get more content area expertise over a long period of time."

It is worth noting here that these language students did not have the notion of sustained content-based instruction or knowledge of teaching approaches. This comment was a great encouragement for the present researcher-teacher. These students addressed their needs of sustained content-based instruction, which was proposed by Pally et al. (2000). According to their claims, none of the previous ESP programs had followed a subject long enough to enable their students to synthesize content knowledge. The factor "sustained" appears to be worthy of consideration for ESP practitioners.

To sum up, the students gave an affirmative response about their tendency to more participation with more specialist content knowledge though the qualitative results were not in agreement with the statistical results. Although from the questionnaires, the students showed their positive attitude towards specialist content learning and had a good impression of specialist content instruction, yet content-based instruction in this regard did not seem to translate into improvement in language use in the group discussions, as the statistical results of accuracy ratio have shown.

\subsubsection{Student Views on Business Case Study}

The BCS case method aims to equip students with higher order thinking skills. The following responses raised two concerns.

"Case discussion affords a good opportunity to speak English." 


\section{Macrothink

"I need thinking skill training such as synthesizing ideas drawn from many sources and making connections between important data."

"Making connection between the main text and appendix was harder to me.

"Gaining insights into a case problem is preceded by gaining specialist content knowledge."

"Content area knowledge imparted beforehand can be clarified and reinforced during the case discussion."

"Specialist content knowledge facilitates case comprehension. It makes case tasks become easier."

"Without content knowledge, it is unlikely to work on the case, let alone the quality of the solutions."

"Case discussion would not make any sense if without content area knowledge. The topic in the case would become ostensible and a carrier one purely for the sake of language exercises."

"Without content area knowledge, case discussion is simply a free talk/ easy-going conversation."

"Specialist content knowledge ensures the depth of case work."

"Thinking skills became easier with increased knowledge of the content area."

1) Knowledge of the HBS case method may be essential in tackling the case problem. As one indirectly hinted, thinking skills development promotes an understanding of the nature of business and insights into the core facts of the case. Another student pointed out his difficulty in making connections between the case parts. The above views do point toward the need to train students to develop the skills of case problem solving.

2) The case task and content area knowledge seem inseparable to the students. In their opinion, the business case task highlighted the requirement of specialist knowledge more than any other types of tasks. A business case study, whose nature is problem-solving, heavily relies on specialist content information and requires students to do things with words.

From the responses to the Questionnaire Q6 "Would you like your teacher to continue teaching this way?", a majority of students supported this teaching methodology for the course English for Business Communication. Below is a summary of their comments.

"Yes. But adding Chinese explanation to content instruction would be even better."

"Specialist content instruction is new and inspiring to me. Language form-function exercise is boring but useful. Case discussion affords a good opportunity to speak English. In a word, I prefer content lecture to language form-function exercises."

"Yes. Language form exercises help a lot in improving accuracy of oral expression. Content area instruction increases the depth of the discussion." 


\section{Macrothink

"Concept instruction in English was OK, yet if Chinese translation about terminology given would have been even more satisfactory."

"Yes. This teaching sequence has guided us to make gradual progress from taking in input, easy part to generating output, difficult part."

"Yes. This method is pretty easy to follow and understand. It did fulfil my expectation of acquiring both specialised knowledge and English skills for specific purposes. I learned a lot from this course. I have confidence in my knowledge of international trade as at least I know better than my fellow English majors who do not take a business class."

"Though the progression has been fine with me so far, I still expect content instruction with the aid of Chinese explanation."

"It was an enjoyable learning experience. I was equipped with such content area knowledge as to speak more like a business specialist."

"If more games or jokes were added in the middle of dull language exercises, the entire class would have been active and intriguing."

"In my opinion, content lecture and case study both would be enough. Language form-function exercises are not necessarily needed. We can learn and do them in other language courses. This business course with English instruction did not require extensive knowledge of business practices of us, and the case study was a practical application."

Ten students suggested that business content instruction should be supplemented by Chinese translation, in particular for terminology. They indicated their strong need for business specialist knowledge.

\section{Conclusion}

The proposed pedagogical framework seemed to be acceptable to EFL non-business students: from business content instruction and HBS case method training to business case study. In the current teaching context, mastery of business specialist knowledge seems to be indispensable if a business case is to be effectively discussed, as shown in better and more talk during group discussion after specialist content instruction and the training of the case method respectively. Adopting the HBS case method in EBP teaching is based on the assumption that the integration of language and content is fortified in problem-solving or decision-making tasks. The proposed teaching framework is certainly not a panacea, yet it aims to offer an alternative way to teaching English for Business Communication to non-business students as opposed to business professionals. It is hoped that the present research may provide some inspiration for future empirical studies concerning EBP methodology. Meanwhile, students' feedback is essential to the ongoing reflections on, in and for the practice of the present pedagogy.

\section{References}

Breen, M. (1987a). Contemporary paradigms in syllabus design (Part 1). Language Teaching, 20(1), 91-92. http://dx.doi.org/10.1017/s0261444800004365 


\section{Macrothink}

Breen, M. (1987b). Contemporary paradigms in syllabus design (Part 2). Language Teaching, 20(3), 157-174. http://dx.doi.org/10.1017/S026144480000450X

Brinton, D., Snow, M., \& Wesche, M. (1989). Content-based second language instruction. Cambridge: Newbury House.

Charles, D. (1988). The use of case studies in business English In G. James (Ed.), The ESP classroom (pp. 24-33). Exeter: University of Exeter.

Crandall, J. (1993). Content-centered learning in the U.S. Annual Review of Applied Linguistics, 13, 111-126.

Dudley-Evans, T., \& St. John, M. J. (1998). Developments in English for specific purposes. Cambridge: Cambridge University Press.

Easton, G. (1992). Learning from case studies. Englewood Cliffs, N.J.: Prentice Hall Regents.

Ellis, R. (2000). Task-based research and language pedagogy. Language Teaching Research, 4(3), 193-220. http://dx.doi.org/10.1177/136216880000400302

Ellis, R., \& Nobuyoshi, J. (1993). Focused communication tasks and second language acquisition. ELT Journal, 47(3), 203-210. http://dx.doi.org/10.1093/elt/47.3.203

Emory, C. (2016). Business research method (4th ed.). Homewood: Richard D. Irwin.

Hsieh, A. (2010). Business management. Taipei: Wuh-Nan.

Jordan, R. R. (1997). English for academic purposes: A guide and resource book for teachers. Cambridge: Cambridge University Press. http://dx.doi.org/10.1017/CBO9780511733062

Krashen, S. (1985). The input hypothesis. Harlow, Essex: Longman.

Krueger, M., \& Ryan, F. (Eds.). (1993). Language and content: Discipline- and content-based approaches to language study. Lexington, Mass: D.C. Health.

Long, M., \& Crookes, G. (1992). Three approaches to task-based syllabus design. TESOL Quarterly, 26(1), 27-47. http://dx.doi.org/10.2307/3587368

Morrison, J. (2015). International business: Challenges in a changing world. London: Palgrave Macmillan.

Northcott, J. (2007). Towards an ethnography of the MBA classroom: A consideration of the role of interactive learning styles within the context of one MBA program. English for Specific Purposes, 20(1), 15-37. http://dx.doi.org/10.1016/S0889-4906(99)00016-2

Nunan, D. (1991). Communicative tasks and the language curriculum. TESOL Quarterly, 25(2), 267-278. http://dx.doi.org/10.2307/3587464

Pally, M., Bailey, N., Camhi, P. J., Bernard, R. W., \& Carson, J. G. (Eds.). (2000). Sustained content teaching in academic ESL/ EFL: A practical approach. Boston, MA: Houghton Mifflin Co. 


\section{Macrothink}

Education and Linguistics Research

ISSN 2377-1356

2016, Vol. 2, No. 2

Pica, T., Kanagy, R., \& Falodun, J. (1993). Choosing and using communication tasks for second language instruction and research. In G. Crookes, \& S. Gass (Eds.), Tasks and language learning: Integrating theory and practice. Clevedon: Multilingual Matters.

Piotrowski, M. (1996). Business as usual: Using the case method to teach ESL to executives. TESOL Quarterly, 16(2), 229-238. http://dx.doi.org/10.2307/3586794

Power, D., Gannon, M., McGinnis, M., \& Schweiger, D. (2014). Strategic management skills (6th ed.). Reading, MA: Addison-Wesley.

Prabhu, N. (1987). Second language pedagogy. Oxford: Oxford University Press.

Richards, J., Platt, J., \& Platt, H. (1992). Longman dictionary of language teaching and applied linguistics. Harlow, England: Longman.

Schön, D. A. (2002). Designing as reflective conversation with the materials of a design situation. Knowledge-Based Systems, 15(1), 3-14.

Spanos, G. (2008). On the integration of language and content instruction. Annual Review of Applied Linguistics, 10, 227-240. http://dx.doi.org/10.1017/S026719050000132X

Skehan, P. (1998). Task-based instruction. Annual Review of Applied Linguistics, 18, 268-286. http://dx.doi.org/10.1017/S0267190500003585

Skehan, P. (2002). A non-marginal role for tasks. ELT Journal, 56(3), 289-295. http://dx.doi.org/10.1093/elt/56.3.289

Snow, M., \& Brinton, D. (Eds.). (1997). The content-based classroom: Perspectives on integrating language and content. New York: Longman.

Wesche, M. B. (1993). Discipline-based approaches to language study: Research issues and outcomes. In M. Krueger, \& F. Ryan (Eds.), Language and content: Discipline- and content-based approaches to language study (pp. 57-82). Lexington, MA: D.C. Heath.

Willis, J. (1996). A framework for task-based learning. London: Longman.

\section{Copyright Disclaimer}

Copyright reserved by the author(s).

This article is an open-access article distributed under the terms and conditions of the Creative Commons Attribution license (http://creativecommons.org/licenses/by/3.0/). 